\title{
KEBIJAKAN PEMERINTAH TERHADAP IMPLEMENTASI CONVENTION ON THE ELIMINATION OF ALL FORMS DISCRIMINATION AGAINTS WOMEN (CEDAW) ATAS HAK PEREMPUAN DI INDONESIA.
}

\author{
Oleh: \\ Ade Yuliany Siahaan ${ }^{1)}$ \\ Fitriani $^{2)}$ \\ Universitas Darma Agung, Medan 1,2) \\ E-mail: \\ $\frac{\text { yulianysiahaan01@gmail.com }^{1)}}{\text { fitrianish89@yahoo.com }^{2)}}$
}

\begin{abstract}
In the relationship between social groups, an imbalance of power often arises which triggers discrimination. Gender differences are one of the reasons for discrimination, not only in Indonesia but also in international community. Women often feel injustice because they are considered weak and have limited rights compared to men even though women's rights are actually part of human rights. The Indonesian government protects women's rights in the 1945 Constitution of the Republic of Indonesia, but this does not necessarily reduce discrimination in the environment. Various government policies and efforts by the Indonesian people have been carried out to eradicate discrimination and protect women's rights. One of the Indonesian government's efforts to protect women's rights is to ratify conventions relating to women and discuss the elimination of discrimination, namely the Convention for the Elimination of All Forms of Discrimination Against Women (CEDAW). This convention is a new milestone for the Indonesian government's policy in protecting women's rights in Indonesia.
\end{abstract}

Keywords: Women's Rights, CEDAW, Indonesian Government Policy

\begin{abstract}
ABSTRAK
Dalam hubungan antar kelompok sosial sering kali muncul ketidakseimbangan kekuatan sehingga memicu timbulnya diskriminasi.Perbedaan gender merupakan salah satu alasan terjadinya diskriminasi,bukan hanya di Indonesia melainkan juga pada masyarakat internasional. Perempuan kerap merasakan ketidakadilan karena dianggap lemah dan memiliki keterbatasan hak dibandingkan lelaki padahal hak perempuan sesungguhnya juga bagian dari hak asasi manusia.Pemerintah Indonesia melindungi hak Perempuan dalam Konstitusi Undang-undang Dasar Negara Republik Indonesia tahun 1945, namun hal ini tak serta merta mengurangi diskriminasi dilingkungan masyarakat.Berbagai kebijakan pemerintah serta usaha masyarakat Indonesia dilakukan untuk memberantas diskriminasi dan melindungi hak-hak perempuan.Salah satu usaha pemerintah Indonesia dalam melindungi hak perempuan ialah dengan meratifikasi konvensi yang berkenaan dengan kaum perempuan serta membahas penghapusan diskriminasi yakniConvention for theElimination of All Forms of Discrimination Against Women (CEDAW). Konvensi ini menjadi tonggak baru bagi kebijakan pemerintah Indonesia dalam melindungi hak-hak perempuan di Indonesia.
\end{abstract}

Kata kunci : Hak Perempuan, CEDAW, Kebijakan Pemerintah Indonesia 


\section{PENDAHULUAN}

Berdasarkan bentuknya, diskriminasi yang kerap kita jumpai dalam kehidupan masyarakat ialah rasisme dan seksisme. Dalam kamus besar bahasa Indonesia, rasisme atau rasialisme merupakan paham bahwa ras diri sendiri adalah ras yang paling unggul dibanding yang lain. Tidak berbeda jauh dengan rasisme, seksisme juga demikian.Seksisme diartikan sebagai sebuah tindakan diskriminasi yang dilakukan oleh kaum pria terhadap kaum perempuan.Dalam hal ini, kecerdasan dan kekuatan fisik kaum pria dianggap lebih tinggi dibandingkan kaum perempuan. Pandangan tersebut tentu tidak adil, mengingat seluruh manusia memiliki hak yang sama, baik di hadapan Tuhan maupun dihadapan hukum.

Undang-Undang Dasar 1945 pasal 27 ayat (1) menyatakan bahwa pengakuan terhadap prinsip persamaan bagi seluruh warga negara tanpa kecuali.Prinsip persamaan ini secara tidak langsung menentang tentang adanya diskriminasi.Pengertian diskriminasi sendiri tertuang dalam undang-undang No. 39 tahun 1999 pasal 1 ayat (3) Tentang Hak Asasi Manusia. Pada undang-undang tersebut dijelaskan bahwa diskriminasi adalah setiap pembatasan, pelecehan atau pengucilan yang langsung ataupun tidak langsung didasarkan pada pembedaan manusia atas dasar agama, suku, ras, etnik, kelompok, golongan, status sosial, status ekonomi, jenis kelamin, bahasa, keyakinan politik, yang berakibat pengurangan, penyimpangan atau penghapusan pengakuan, pelaksanaan atau penggunaan hak asasi manusia dan kebebasan dasar dalam kehidupan baik individual maupun kolektif dalam bidang politik, ekonomi, hukum, sosial, budaya, dan aspek kehidupan lainnya.

Perjuangan kaum perempuan dalam mencapai kesetaraan dan keadilan yang telah dilakukan sejak lama, ternyata belum dapat mengangkat harkat dan martabat kaum perempuan untuk dapat sejajar dengan kaum laki-laki. Sekalipun kekuasaan tertinggi di negeri ini pernah dipegang oleh perempuan, yakni Presiden Megawati Soekarno Putri pada tahun 2001 serta saat ini Sri Mulyani dan beberapa perempuanhebat lainnya memegang jabatan strategis dalam pemerintahan, ketidakadilan gender (Avveroes Press 2008:3-5) dan ketertinggalan kaum perempuan masih belum teratasi sebagaimana yang diharapkan.

Penelitian ini bertujuan untuk mengetahui dan memahami upaya pemerintah dalam melindungi hak perempuan di Indonesia, memahami bentuk hak-hak perempuan menurut konvensi $C E D A W$ serta mengetahui dan memahami bentuk kebijakan pemerintah terhadap implementasi CEDAW di Indonesia. Berdasarkan tujuan tersebut, penelitian ini menggunakan metode pendekatan yuridis normatif, yaitu dengan cara mengkaji dan menguji aspek-aspek hukum yang terkait dan pelaksanaannya, yakni bagaimana hak perempuan sejatinya menurut konvensi CEDAW serta kebijakan pemerintah terhadap implementasi konvensi tersebut atas hakhak perempuan di Indonesia.

\section{TINJAUAN PUSTAKA}

Bahan hukum primer yaitu bahan hukum yang mengikat dan otoratif. Bahan hukum ini diperoleh dari peraturan perundang-undangan yang terkait dengan pengaturan kebijakan pemerintah terhadap hak perempuan di Indonesia, diantaranya:

1. Undang-undang Dasar Negara Republik Indonesia Tahun 1945;

2. Undang-undang Republik Indonesia Nomor 7 Tahun 1984 Tentang Ratifikasi Konvensi Penghapusan Segala Bentuk Diskriminasi Terhadap

Perempuan.

3. Undang-undang Republik Indonesia Nomor 39 Tahun 1999 Tentang Hak Asasi Manusia.

Bahan hukum sekunder, yakni penjelasan mengenai bahan primer. Bahan hukum sekunder diperoleh dari : 
1. Karya-karya tulis ilmiah, artikelartikel dari media cetak, serta pendapat sarjana yang terkait dengan masalah yang diteliti;

2. Kajian literature buku-buku yang sesuai dengan judul penelitian;

3. Artikel-artikel dari media elektronik yang berkaitan dengan konvensi $C E D A W$.

Bahan hukum tersier merupakan bahan yang memberikan petunjuk maupun penjelasan terhadap bahan hukum primer dan sekunder seperti kamus hukum, kamus besar bahasa Indonesia dan Kamus bahasa Inggris-Indonesia.

\section{HASIL DAN PEMBAHASAN}

\section{A. Upaya Pemerintah Dalam Melindungi Hak Perempuan di Indonesia.}

Pada awalnya perlindungan atas hak perempuan hanya terdapat dalam ketentuan Undang-Undang Dasar 1945 saja. Selain peraturan perundangundangan, masyarakat Indonesia khususnya perempuan juga memperjuangkan hak dan harkatnya dengan mendirikan organisasi-organisasi yang secara khusus bergerak dalam hal tersebut, diantaranya Gerakan Wanita Indonesia (GERWANI), Poetri Mardika, Badan Musyawarah Organisasi Islam Wanita Indonesia (BMOIW), Koalisi Perempuan Indonesia dan organisasi lainnya.Kebijakan untuk mengatasi diskriminasi terhadap kaum perempuan bukan hanya datang dari pemerintah Indonesia saja, melainkan juga dari dunia internasional.Isu mengenai ketimpangan hak tersebut, direspon oleh Perserikatan Bangsa-Bangsa $(P B B)$ melalui

CEDAW(Convention on the Elimination of All Forms of Discrimination Againts Women).Perumusan $C E D A W$ berawal dari Bill of Rights of Women atau Pernyataan tetap Hak-hak Perempuan sebagai Hak Asasi Manusiadalam Sidang Majelis Umum PBB pada tanggal 18 Desember 1979.
Perumusan ini diawali dengan perhatian khusus Majelis Umum PBB terhadap sebuah rancangan konvensi tentang Penghapusan Segala Bentuk Diskriminasi terhadap Perempuan.Konvensi ini kemudian diratifikasi pada 1981 dan disetujui oleh 20negara, tujuannya untuk melindungi dan mengenalkan hak-hak perempuan pada dunia Internasional. Hal ini disikapi oleh Komisi Kedudukan Perempuan (UN Commission on the Status of Women) sebuah badan yang dibentuk oleh PBB pada tahun 1947 sebagai dewan pertimbangan serta penyusun kebijakan untuk meningkatkan kualitas dan posisi perempuan. (Hans Kelsen 2001:13).CEDAW merupakan salah satu konvensi utama tingkat internasional yang membela hak-hak perempuan sebagaimana tercantum dalam resolusi Mahkamah Umum No. 34/180 tanggal 18 Desember 1979 yang disusun untuk diadopsi dan diratifikasi oleh negara-negara anggota PBB. $C E D A W$ memuat 30 pasal dan secara formal dan legal dinyatakan sebagai dokumen internasional (entry into force) tanggal 3 September 1981.Indonesia resmi meratifikasi $C E D A W$ pada tanggal 24 Juli 1984 melalui Undang-Undang No. 7 Tahun 1984.

Di Indonesia, penghapusan diskriminasi terhadap wanita dan perlindungan hak wanita maupun perubahan hukum jauh lebih rumit dari aturan hukum Internasional. Pelaksanaan $C E D A W$ mengandung persoalan di bidang politik, terutama setelah penggantian pemerintah Orde Baru dengan pemerintah era reformasi.Persoalan politik ditambah dengan masalah sosial, yaitu perbedaan pendapat dalam masyarakat mengenai agama dan kebudayaan. (Jimly Assiddiqie 2010:120). Kendati demikian, negaranegara di dunia selaku anggota PBB memiliki kewajiban menaati ketentuan konvensi tersebut.Hukum nasional tidak dibenarkan mengurangi pelaksanaan suatu perjanjian internasional, jika demikian hukum nasional wajib diubah.Pada pasal 7 
ayat (2) Undang-Undang Nomor 39 Tahun 1999 Tentang Hak Asasi Manusiamengatur bahwa ketentuan hukum internasional yang telah diterima Negara Indonesiayang menyangkut Hak Asasi Manusia (HAM) menjadi hukum nasional.

\section{B. Hak Perempuan menurut $C E D A W$.}

Lahirnya diskriminasi terhadap perempuan baik pada tingkat nasional maupun internasional, bermula dari struktur sosial dalam masyarakat yang bersifat patriarkhi.Implikasi yang lahir dari budaya semacam ini adalah marginalisasi, subordinasi, dan stereotype baik pada wilayah publik maupun domestik. Bentuk kepemimpinan dalam struktur masyarakat yang dipegang oleh pihak laki-laki dan struktur yang dibawa laki-laki ini kemudian dianggap menjadi norma. (Amina Wadud Muhsin 2001:145). Kemunculan ratifikasi CEDAW dipicu oleh Deklarasi Universal Hak Asasi Manusia (DUHAM) yang membentuk perangkat hukum yang universal.Dalam hal ini kaum perempuan merasa bahwa deklarasi tersebut belum sepenuhnya mampu menjamin kepentingan mereka.Bahkan kaum feminis menyatakan bahwa deklarasi tersebut tidak berperspektif keadilan gender.Berbagai kasus seperti perkosaan di wilayah konflik, mutilasi genital, kekerasan domestik, dan diskriminasi pekerjaan misalnya, tidak bisa ditangani hanya oleh deklarasi HAM.Maka, untuk mengatasi berbagai problem tersebut, dunia Internasional menoleh pada $C E D A W$. (Sobar Hartini 2003).

$C E D A W$ terdiri atas tiga puluh pasal mencakup materi berbeda. Pada pasal 1-16 Undang-Undang tentang $C E D A W$ mendiskusikan tentang prinsipprinsip dalam KonvensiCEDAW, dimana memuat 3 (tiga) prinsip utama, yakni: Pertama, Prinsip KesetaraanSubstantif , prinsip ini dikenal juga dengan pendekatan korektif yaitupendekatan yang tidak berfokus pada perlakuan yang sama di depanhukum saja tetapi juga mencakup kesetaraan dalam arti de juredampakaktual atau riil dari hukum. Kedua, Prinsip NonDiskriminasi, pengertian diskriminasidalam konvensi ini sama seperti defenisi diskriminasi yang tertuang dalam Undang-Undang tentang Hak Asasi Manusia.Ketiga, Prinsip Kewajiban Negara.Menurut Achi Sudiarti Luhulimaprinsip ini meliputi hal-hal diantaranya menjamin hak perempuan melalui hukum dan kebijakan serta menjamin hasilnya, menjamin pelaksanaan praktis dan hak melalui langkah tindak atau aturan khusus sementara, menciptakan kondisi yang kondusif untuk meningkatkan kesempatan dan akses perempuan pada peluang yang ada dan menikmati manfaat yang sama/adil dari hasil menggunakan peluang itu, Negara tidak saja menjamin tetapi juga merealisasi hak perempuan.

Mengenai Hak perempuan, berdasarkanCEDAW, dapat dilihat pada pasal 7-16Undang-Undang tentang konvensi CEDAW.Berikut beberapa hak perempuan menurut pasal-pasal dalam CEDAW :

1. Hak menikmati kondisi kerja yangadil dan menguntungkan (pasal 7);

2. Hak untuk membentuk serikatpekerja, terlibat dalam serikat pekerja (pasal 8);

3. Hak atas jaminan sosial dan asuransi sosial (pasal 9);

4. Hak mendapat perlindungan dalammembentuk keluarga (pasal 10);

5. Hak mendapat perlindungan khusus terhadap kehamilan (pasal 10);

6. Hak mendapat perilaku yang non diskriminatif (pasal 10);

7. Hak atas standar kehidupan yang layak (pasal 11);

8. Hak atas standar tertinggi kesehatan (pasal 12);

9. Hak atas pendidikan (pasal 13);

10. Hak berpartisipasi dalam kehidupan budaya, penikmatan manfaat teknologi dan kemajuan teknologi (pasal 15);

11. Hak mendapat perlindungan atas karya dan budaya (pasal 15). 
Pasal $16 \quad$ Konvensi

Perempuanmenjamin tentang hak-hak perempuan didalam perkawinan.Berikut diantaranyahak perempuan yang ditegaskan pada pasaltersebut.(Arifah Milati Agustina 2016:206).

Dalam pasal 16 huruf (a) disebutkan hak yang sama antara pria dan wanita untuk melakukan ikatan perkawinan; huruf (b), hak-hak yang sama untuk memilih dengan bebas pasangan hidupnya dan untuk masuk ke dalam ikatan perkawinan hanya dengan persetujuan bebas dan sepenuhnya; huruf (c) mensyaratkan hak-hak dan tanggung jawab yang sama selama perkawinan dan pada pemutusan perkawinan;huruf (d) mengakui hak pribadi yang sama sebagai suami istri termasuk hak memilih nama, keluarga, profesi dan jabatan; huruf (f) mensyaratkan hak yang sama untuk kedua suami dan istri berkaitan dengan benda. Pasal 16 ayat 2 melarang pertunangan dan perkawinan seorang anak (nikah dini); Hak sama untuk suami istri berhubungan dengan pemilikan atas perolehan pengelolaan harta benda.

Menurut Maria Ulfah Anshor, $C E D A W$ juga menjamin hak perempuan melalui pasal 12 ayat (2) mengenai ketentuan-ketentuan tentang hak perempuan dan kewajiban Negara dalam menjamin pelayanan kesehatan reproduksi perempuan yakni memastikan pelayanan yang layak untuk perempuan dan hubunganya dengan kehamilan, persalinan, dan pasca persalinan, bila perlu menyediakan pelayanan gratis; dan memastikan perempuan mendapatkan gizi yang cukup selama masa kehamilan dan menyusui.

\section{Kebijakan Pemerintah Terhadap Implementasi $C E D A W$ Di Indonesia.} Pasca ratifikasi CEDAW sudah dilakukan kebijakan pemerintah melalui upaya untuk memperbaiki peraturan perundang-undangan yang ada baik yang secara langsung berkaitan dengan perempuan maupun tidak. Beberapa peraturan perundang-undangan itu, antara lain:

1. Undang-Undang Nomor 39 Tahun 1999 tentang Hak Asasi Manusia.

2. Undang-Undang Nomor 23 Tahun 2004 tentang Penghapusan Kekerasan Dalam Rumah Tangga.

3. Undang-Undang Nomor 12 Tahun 2006 tentang Kewarganegaraan.

4. Undang-Undang Nomor 13 Tahun 2006 tentang Perlindungan Sanksi dan Korban.

5. Undang-Undang Nomor 21 Tahun 2007 tentang Pemberantasan Tindak Pidana Perdagangan Orang.

6. Undang-Undang Nomor 10 Tahun 2008 tentang Pemilihan Umum.

7. Undang-Undang Nomor 44 Tahun 2008 tentang Pornografi.

8. Undang-Undang Nomor 11 Tahun 2009 tentang Kesejahteraan Sosial.

9. Undang-Undang Nomor 36 Tahun 2009 tentang Kesehatan.

10. Undang-Undang Nomor 16 Tahun 2011 tentang Bantuan Hukum.

11. Peraturan Pemerintah Nomor 4 Tahun 2006 tentang Penyelenggaraan dan Kerjasama Pemulihan Korban Kekerasan Dalam Rumah Tangga.

12. Peraturan Pemerintah Nomor 9 Tahun 2008 tentang Tata Cara dan Mekanisme Pelayanan terpadu Bagi Saksi dan/atau Korban Tindak Pidana Perdagangan Orang.

13. Instruksi Presiden Nomor 9 Tahun 2000 tentang Keharusan Melaksanakan Pengarusutamaan Gender (PUG) di seluruh Bidang Pembangunan Tingkat Nasional Maupun Daerah.

Kebijakan pemerintah dalam merevisi atau membuat peraturan perundang-undangan baru juga harus dilaporkan kedalam bentuk laporan periodik $C E D A W$ yang harus dibuat dalam rentan waktu 7 (tujuh) tahun sekali.Dalam hal ini, berdasarkan urutannya Pemerintah Indonesia sampai pada tahun 2019 telah 
membuat 8 laporan semenjak diratifikasinya konvensi tersebut. Dalam 7 tahun pertama ada 4 laporan periodik (tahun 1984-1991), kemudian laporan ke-5 (tahun1998), laporan ke-6 (tahun 2005), laporan ke-7 (tahun 2012) dan laporan ke8 (tahun 2019). Berikut adalah isi dari Laporan periodik CEDAW ke-8:

Dalam implementasi UndangUndangCEDAW, pemerintah mengadaptasikan nilai-nilai pemberdayaan perempuan kedalam Rencana Pembangunan Jangka Menengah Nasional (RPJMN). Tujuannya berfokus kepada isi pemberdayaan perempuan:

1. Peran perempuan dalam pembangunan;

2. Perlindungan perempuan terhadap kekerasan;serta

3. Kapasitas kelembagaan dalam pengarusutamaan gender dan perlindungan perempuan.

Upaya dalam mempromosikan nilai-nilai tersebut merupakan hal penting yang memerlukan partisipasi aktif dari berbagai pemangku kepentingan. Dukungan pemberdayaan gender dipelopori oleh sejumlah lembaga pemerintah bekerja sama dengan organisasi masyarakat sipil (Civil Society Organizations - CSOs), serta Kementerian Pemberdayaan Perempuan dan Perlindungan Anak (KPPPA) sebagai penanggung jawab teknis (focal point). Kebijakan pemerintah ini telah dilaporkan pada tahun 2017 dimanaIndeks Pembangunan Gender (IPG) Indonesia telah meningkat dari 90.07 ke 90.99 ditahun 2018, selain itu Indeks Pemberdayaan Gender (IDG) mengalami peningkatan yang lebih signifikan sejak tahun 2012, dari 70.07 ke 72.10 ditahun 2018. Peningkatan ini menunjukkan konsistensi upaya yang dilakukan oleh pemerintah dalam sejumlah sektor, salah satunya pendidikan.Pemerintah telah memasukan sejumlah program untuk memastikan lebih banyak perempuan dan anak-anak yang memiliki akses terhadap pendidikan dengan menyediakan dukungan berupa anggaran, bantuan keuangan, serta program pengembangan kapasitas.

Sementara diranah politik, partisipasi perempuan meningkat dengan adanya 3.194 perempuan (setara dengan $40 \%$ dari total kandidat) yang mencalonkan diri sebagai anggota legislatif dalam Pemilihan Umum (Pemilu) 2019. Pada sektor ekonomi, peraturan telah diimplementasikan guna menyediakan lebih banyak kesempatan bagi perempuan untuk berkontribusi dalam perekonomian, seperti memfasilitasi pinjaman mikro dan pembangunan kapasitas untuk mendukung lebih banyak pengusaha perempuan.Dukungan terhadap pekerja perempuan juga telah ditingkatkan dengan adanya kebijakan yang mewajibkan pemberi kerja menyediakan hak untuk cuti hamil, ruang laktasi, dan pusat penitipan anak serta jam kerja fleksibel bagi perempuan menyusui.

Berbagai program tentang keterlibatan perempuan dalam keuangan rumah tangga telah secara signifikan berdampak pada perekonomian dengan berkurangnya angka kemiskinan sebesar $0.52 \%$, serta tingkat ketidaksetaraan dan pengangguran.Kemudian untuk mengatasi Angka Kematian Ibu (AKI), Pemerintahsecara konsisten meningkatkan akses terhadap pelayanan kesehatan.

Pemerintah bekerja sama dengan lembaga HAM nasional, diantaranya Komisi Perlindungan terhadap Kekerasan Perempuan (Komnas Perempuan) dan Komisi Perlindungan Anak Indonesia (KPAI), yang secara khusus diamanatkan untuk mempromosikan hak-hak perempuan dan anak, serta membangun lingkungan yang memungkinkan penghapusan segala bentuk kekerasan terhadap perempuan dan anak-anak di Indonesia. Pemerintah juga bekerja sama dengan Komisi Hak Asasi Manusia (Komnas HAM), Ombudsman, dan Lembaga Perlindungan Saksi dan Korban (LPSK) tentang berbagai masalah yang 
berkaitan dengan promosi dan perlindungan tentang hak-hak perempuan.

KPPPA sebagai mekanisme pemantauan dalam mengimplementasikan pengarusutamaan gender, telah mengeluarkan Peraturan KPPPA No. 07/2018 sebagai pengganti No.09/2015 tentang Indikator Pemantauan dan Evaluasi tentang Implementasi Pemberdayaan Perempuan dan Perlindungan Anak yang disebut penghargaan Anugrah Parahita Ekapraya. Penghargaan ini diberikan setiap dua tahun sekali dengan memilih pemerintah daerah dan pusat yang telah menunjukkan upaya terbaik dalam mempromosikan dan mengarusutamakan kesetaraan gender di bidang dan daerah masing-masing.

Pada kerangka hukum dan kelembagaan, Indonesia telah menerbitkan kerangka kerja undang-undang dan kebijakan baru untuk mempromosikan pemberdayaan perempuan serta melindungi hak-hak perempuan dan anak perempuan. Hal-hal penting dari kebijakan pemerintah yang dikeluarkan tersebut adalah antara lain:

1. Undang-Undang No. 6/2014 tentang Desa. Undang-Undang ini mendukung prinsip partisipasi, kesetaraan dan pemberdayaan perempuan dalam proses sosial ekonomi serta pengambilan keputusan;

2. Undang-Undang No. 7/2014 tentang Konflik Sosial dan peraturan lanjutan dari Menteri Koordinator Kesejahteraan Rakyat No.8/2014 mengenai Kelompok Kerja Perlindungan dan Pemberdayaan Perempuan dan Anak dalam Konflik Sosial,

3. Peraturan Menteri No.7/2014 tentang Rencana Aksi Nasional untuk Perlindungan dan Pemberdayaan Perempuan dan Anak dalam Konflik Sosial (RANP3AKS).

Ada pula Undang-Undang No.18/2014 tentang Kesehatan Mental, dimana undang-undang mewajibkan rumah sakit jiwa untuk menyediakan ruangan terpisah bagi perempuan dan anak-anak, lalu Undang-Undang No. 23/2014 tentang Pemerintah Daerah serta amandemennya, mengamanatkan pemerintah pusat dan daerah untuk Menyusun kebijakan terkait pemberdayaan dalam beberapa isu seperti perlindungan perempuan dan anak, kualitas hidup perempuan, pemenuhan hak anak-anak, serta sistem data perempuan dan anak.

Sementara itu, pemerintah juga melakukan revisi terhadap UndangUndang No. 13/2006 menjadi No. 31/2014 tentang Perlindungan Korban dan Saksi, yang mengatur perlindungan lebih terhadap para perempuan dan anak yang menjadi korban dan saksi tidak hanya selama persidangan tetapi juga sebelum persidangan kemudian Undang-Undang No. 08/2016 tentang Penyandang Disabilitas, langkah progresif dalam perlindungan penyandang disabilitas, termasuk perempuan dan anak-anak. undang-undang tersebut memastikan hak perempuan penyandang disabilitas seperti hak untuk menerima atau menolak penggunaan kontrasepsi, didukung dengan Peraturan Pemerintah No. 61/2014 tentang kesehatan reproduksi, menguraikan lebih jauh tentang hak perempuan atas kesehatan reproduksi.

$\begin{array}{lrrr}\text { Kebijakan } & \text { pemerintah } & \text { juga } \\ \text { tertuang dalam } & \text { Peraturan } & \text { Presiden } \\ \text { (perpres) No. } & 18 / 2014 & \text { tentang } \\ \text { perlindungan } & \text { dan } \quad \text { pemberdayaan }\end{array}$
perempuan dan anak dalam situasi konflik (p3aks).Dalam mengatasi kerentanan perempuan dan anak-anak dalam konflik sosial, peraturan tersebut mengamanatkan pemerintah pusat dan daerah untuk melakukan penyelamatan, perlindungan, rehabilitasi, serta pemenuhan kebutuhan spesifik dan dasar bagi perempuan dan anak-anak.Untuk membangun langkahlangkah terkoordinasi, peraturan tersebut mensyaratkan keberadaan kelompok kerja dan rencana aksi nasional.Saat ini kelompok kerja telah dibentuk dan rencana 
aksi dinyatakan dalam Peraturan Kemenko PMK No.7/2014.

Disisi lain terdapat Peraturan Mahkamah Agung No. 3/2017 tentang Pedoman Mengadili Perkara Perempuan Berhadapan dengan Hukum. Peraturan ini menyatakan tugas negara untuk memastikan perempuan memiliki akses terhadap keadilan dan bebas dari diskriminasi dibawah sistem peradilan.Peraturan ini juga disebutkan secara spesifik kode etik bagi para hakim dalam menangani perkara.

Kementerian Pemberdayaan Perempuan dan Perlindungan Anak juga mengeluarkan beberapa peraturan diantaranya:

1. Permen PPPA No. 10/2015 tentang Grand Design Peningkatan Keterwakilan Perempuan di DPR, DPD, DPRD pada Pemilu Tahun 2019. KPPPA menyediakan langkah-langkah panduan bagi seluruh pemangku kepentingan terutama partai politik agar menciptakan lingkungan yang kondusif untuk mendorong perwakilan perempuan.

2. Permen PPPA No. 2/2017 tentang Partisipasi Masyarakat dalam Pembangunan Pemberdayaan Perempuan dan Perlindungan Anak. Peraturan ini menetapkan kerangka kerja bagi masyarakat untuk ikut berperan dalam pengembangan pemberdayaan perempuan dan perlindungan anak melalui strategi gender dan Pengarusutamaan Hak Anak (PUHA).

3. Permen PPPA No. 6/2017 tentang Pembentukan Satuan Tugas Penanganan Masalah Perempuan dan Anak. Satuan tugas dibentuk untuk menangani masalah perempuan dan anak-anak yang dilaporkan ke organisasi layanan perempuan di tingkat pemerintah daerah.
Pemerintah daerah juga perlahan turut serta membuat kebijakan dengan dikeluarkannya Peraturan Daerah yang mengurustamakan hak perempuan. Beberapa diantaranya yaitu Peraturan Daerah Provinsi Maluku No. 12/2012 Tentang Penyelenggaraan Perlindungan Perempuan dan Anak Korban Kekerasan, mengamanatkan pembentukkan Lembaga Perlindungan Perempuan dan Anak tingkat provinsiyang menawarkan bantuan kepada korban dalam bentuk medis, psikososial, dan bantuan hukum. Peraturan serupa juga diterapkan oleh Pemerintah daerah Semarang, Kabupaten Batubara dan Yogyakarta.

Disektor global, Undang-Undang No. 12/2017 hasil ratifikasi konvensi ASEAN menentang perdagangan orang, khususnya perempuan dan anak-anak. Ratifikasi konvensi ini menekankan komitmen indonesia dalam memberantas perdagangan perempuan dan anak-anak.

Sampai saat ini, terdapat 114 Peraturan Daerah yang telah diidentifikasi sebagai perbuatan diskriminatif terhadap perempuan dan dari 114 undang-undang yang tersebut, 3 legislasi telah direvisi, 9 legislasi telah dicabut. Pemerintah juga telah mencabut Permenkes No. 1636/2010 tentang Sunat Perempuan dengan menerbitkan Permenkes No. 6/2014.Peraturan terbaru ini melarang semua praktisi medis dari melakukan prosedur sunat kelamin perempuan.Sementara legislasi lainnya masih dalam tahap peninjauan.

Mengenai pengelolaan dan penanganan kasus, pemerintah Indonesia telah mendirikan pusat layanan terpadu untuk menyediakan mekanisme pencegahan, perlindungan, promosi, rehabilitasi dan reintegrasi bagi korban kekerasan, serta koordinasi di antara para pemangku kepentingan dan satuan tugas nasional tentang perdagangan orang.KPPPA juga menyediakan pengembangan kapasitas bagi petugas lapangan di lembaga terkait tentang penanganan dan pelaporan KTP, 
pengetahuan dalam proses hukum dan penyediaan bantuan hukum, penyediaan layanan kesehatan yang relevan, rehabilitasi sosial, repatriasi dan reintegrasi bagi para korban dan keluarga mereka untuk memastikan kasus-kasus ditangani sebagaimana mestinya.

Menurut data statistik yang diperoleh dari Sistem Informasi untuk Perlindungan Perempuan dan Anak/Sistem Informasi Online Perlindungan Perempuan dan Anak (Simfoni PPA), terdapat 21.428 kasus kekerasan dalam rumah tangga yang tercatat pada tahun 2018, dengan rincian jumlah korban perempuan dewasa sebanyak 8.840 kasus, jumlah korban lakilaki dewasa sebanyak 992 kasus, dan jumlah korban kasus anak sebanyak 12.369.

Pada tahun 2019, 949 dari 2000 petugas penegak hukum yang diproyeksikan telah dilatih untuk mengatasi kasus yang melibatkan perempuan dan anak-anak.Mulai tahun 2017, 567 Unit Pelayanan Perempuan dan Anak-Anak dan 67 Unit Krisis Terpadu pada rumah sakit polisi telah didirikan di seluruh Indonesia.Sejalan dengan hal ini, Pemerintah telah membentuk Gugus Tugas tentang Perdagangan Orang pada 32 Provinsi dan 194 Kabupaten/Kota.

Pemerintah telah mengimplementasikan strategi yang spesifik dan terarah untuk mengatasi kekerasan terhadap perempuan dengan membentuk mekanisme pencegahan, menguatkan pengelolaan kasus, dan meningkatkan pemberdayaan perempuan. Bentuk mekanisme pencegahan tersebut antara lain:

1. Mendorong pemerintah daerah untuk menerbitkan hukum tentang perlindungan perempuan dan anakanak terhadap kekerasan;

2. Menerbitkan Permen PPPA No. 4/2018 tentang Pedoman Pembentukan Unit Pelaksana Teknis Daerah Perlindungan Perempuan dan Anak;
3. Membangun forum koordinasi pada setiap provinsi untuk mengatasi masalah kekerasan terhadap perempuan (Gugus Tugas Perdagangan Orang);

4. Melakukan advokasi dan kampanye untuk mengajak para laki-laki berusia 15 hingga 30 tahun untuk berpartisipasi dalam pencegahan kekerasan dalam rumah tangga dan memberdayakan mereka untuk mendukung korban kekerasan dalam melaporkan tindak kekerasan dalam rumah tangga;

5. Melakukan advokasi prapernikahan tentang kekerasan dalam rumah tangga untuk pasangan sebagai bagian dari kursus dasar pra-pernikahan yang diselenggarakan oleh Kemenag;

6. Menerbitkan Pedoman Pencegahan Kekerasan Seksual di Tempat Kerja, seperangkat rekomendasi untuk perlindungan perempuan terhadap kekerasan seksual dan proses penyelesaian untuk korban dan pelaku;

7. Berkolaborasi dengan universitas nasional di seluruh Indonesia dalam mempromosikan "Kampus Responsif Gender" dan mengajak para akademisi serta pemuda dalam meningkatkan kepedulian terhadap kesetaraan gender di kampus maupun ruang publik;

8. Mengimplementasikan Temu Penguatan Anak dan Keluarga sebagai forum berbagi pengetahuan dan mencari penyelesaian bagi isu terkait anak dalam masyarakat, termasuk kasus kekerasan terhadap anak-anak;

9. Menyelenggarakan Sakti Peksos Goes to School, sebuah program nasional tentang Anti-Penindasan dan Kekerasan terhadap Anakanak;

10. Mengerahkan 806 pekerja sosial dalam menghadapi isu anak, 
menyediakan layanan konseling individu, kelompok, dan keluarga serta manajemen kasus untuk wanita dan anak-anak yang rentan;

11. Membentuk Sesi Pembentukan Keluarga (SPK) yang bertujuan untuk meningkatkan pelaksanaan dan mendorong perubahan tingkah laku dari peserta program perlindungan sosial dalam Program Keluarga Harapan (PKH).

Upaya pemerintah melalui kebijakan yang dibuat tentu saja tidak akan berjalan dengan baik apabila tidak selaras dengan kesadaran masyarakat itu sendiri.Meskipun ada beberapa hal yang bertentangan dengan CEDAW terkait kepercayaan dan adat, setidaknya melalui ratifikasi konvensi tersebut Pemerintah Indonesia memiliki suatu tolak ukur baru dalam menciptakan keadilan yang selama ini dirasa kurang akibat adanya diskriminasi terhadap perempuan.Dan berdasarkan laporan periodik yang dibuat, hendaknya masyarakat dapat menilai sampai sejauh mana kesungguhan pemerintah dalam mengimplementasikan konvensi tersebut di Indonesia.

\section{PENUTUP}

A. Kesimpulan

Berdasarkan pembahasan yang telah diuraikan, maka dapat ditarik kesimpulan sebagai berikut :

1. Upaya pemerintah dalam melindungi hak perempuan pada dasarnya tertuang dalam Undang-Undang Dasar 1945 pasal 27 ayat (1) yang menyatakan bahwa pengakuan terhadap prinsip persamaan bagi seluruh warga negara tanpa kecuali. Artinya tidak ada diskriminasi atau perbedaan hak antara kaum perempuan dan kaum pria. Seluruh masyarakat Indonesia, memiliki hak dan kewajiban yang sama dalam berbangsa dan bernegara.

2. Secara khusus hak perempuan diatur dalam Konvensi CEDAW yang telah diratifikasi oleh Pemerintah Indonesia dengan lahirnya Undang-Undang No. 7 Tahun 1984 tentang konvensi terkait, dapat dilihat hak perempuan pada pasal 7-16, diantaranya mengatur tentang hak-hak sipil dan politik perempuan, hak ekonomi, kesehatan, sosial dan budaya kaum perempuan, persamaan hak antara kaum laki-laki dan perempuan dihadapan hukum serta hak perempuan didalam perkawinan.

3. Kebijakan Pemerintah Indonesia terhadap implementasi CEDAW atas hak perempuan dapat dilihat melalui perubahan peraturan yang dirasa ambigu terkait masalah gender bahkan sampai pada pembuatan peraturan baru dan pencabutan peraturan yang dianggap mendukung adanya diskriminasi yang merugikan kaum perempuan. Dan hasil dari implementasi tersebut juga dilaporkan dalam bentuk laporan periodik kepada PBB selaku pengawas Negara anggota konvensi CEDAW sebagai bentuk tanggung jawab Negara dalam implementasi konvensi tersebut demi melindungi hak perempuan di Indonesia.

\section{B. Saran}

1. Untuk menciptakan keadilan yang sesungguhya bukan hanya menjadi tugas penting bagi pemerintah dan penegak hukum saja, tetapi dimulai dari dalam diri sendiri. Dengan demikian diharapkan seluruh masyarakat Indonesia agar bersikap saling menghargai dan menjunjung prinsip persamaan sebagai warga negara tanpa kecuali.

2. Diharapkan agar pemerintah serta penegak hukum di Indonesia dapat memenuhi prinsip-prinsip yang terkandung dalam CEDAW kedalam terhadap hak perempuan bukan hanya secara teoritis (tertulis) melainkan juga dalam praktek dilapangan.

3. Disarankan agar pemerintah maupun para penegak hukum di Indonesia mampu menuntaskan peninjauan 
terhadap legislasi yang masih menyiratkan diskriminasi serta dengan sigap dan adil menyelesaikan kasuskasus tentang pelanggaran hak perempuan yang semakin meningkat dimasa pandemic covid-19 ini.

\section{DAFTAR PUSTAKA}

A. Perundang-undangan

Undang-undang Dasar Negara Republik Indonesia Tahun 1945.

Undang-undang Republik Indonesia Nomor 7 Tahun 1984 Tentang Ratifikasi Konvensi Penghapusan Segala Bentuk Diskriminasi Terhadap Perempuan.

Undang-undang Republik Indonesia Nomor 39 Tahun 1999 Tentang Hak Asasi Manusia.

\section{B. Buku}

Assiddiqie, Jimly. 2010. Perempuan Dan Hak Konstitusi: Perempuan Dalam Relasi Agama Dan Negara, Jakarta: Komisi Nasional Anti Kekerasan terhadap Kaum Perempuan.

Kelsen, Hans. 2001. Hak Asasi Manusia Kaum Perempuan Langkah Demi Langkah, terjemahan LBHAPIK , Jakarta: LBH APIK.

Sudiarti Luhulima, Achi. 2006. "Hak PerempuanDalam Konstitusi" Dalam Perempuan dan Hukum Menuju Hukum yang Berperspektif Kesetaraan dan Keadilan.Yayasan Obor Indonesia.

Sumbulah, Umi. 2008. Gender dan

Demokrasi, Malang: Avveroes Press.

Ulfah Anshor, Maria. 2006. Fiqih
Aborsi: Wacana
Pergulatan
HakReproduksi
Perempuan,
Jakarta: Kompas.

Wadud Muhsin, Amina. 2001. Qur'an

Menurut Perempuan, terj. Abdullah Ali, Jakarta: Serambi Ilmu Pustaka.

Widyani Soetjipto, Ani. 2005. Politik Perempuan Bukan Gerhana, Jakarta: Penerbit Buku Kompas.

\section{Jurnal dan karya Ilmiah}

Hartini, Sobar, Disampaikan dalam Forum Diskusi Interaksi Civil Rights dan Demokratisasi: $\quad$ Pengalaman Indonesia II, di Kuningan, Jawa Barat. 27-29 Januari 2003.

Kania, Dede.Jurnal Konstitusi, Vol.12, No.4 Desember 2015.Hak Asasi Perempuan dalam Peraturan Perundang-undangan.

Maryam, Rini.Jurnal Legislasi Indonesia, Vol.9No. 1, April 2012. Menerjemahkan Konvensi Penghapusan Segala Bentuk Diskriminasi Terhadap Perempuan (CEDAW) kedalam peraturan Perundang-undangan.

Millati Agustina, Arifah.Jurnal Al-ahwal, Vol. 9, No. 2 Desember 2016. Hak-Hak Perempuan Dalam Pengarusutamaan Ratifikasi Cedaw Dan MaqāṢid AsySyarī'Ah.

\section{Internet}

www.kemenpppa.go.id/laporan-periodikcedaw-ke-8-Indonesia-(20122019)/ 